\title{
ANALYSIS AND MODELING OF ENERGY DEMAND SYSTEM IN IRAN'S BUILDINGS AND THE INDUSTRY
}

\author{
EMAMI Seyed Morteza a , RAVANSHADNIA Mehdi a *, RAHIMI Mahmood ${ }^{\text {b }}$ \\ ${ }^{a}$ Islamic Azad University, Department of Civil Engineering, Science and Research Branch, Tehran, Iran, \\ e-mail: * ravanshadnia@gmail.com \\ ${ }^{\mathrm{b}}$ Islamic Azad University, Department of Urban Planning, Central Tehran Branch, Tehran, Iran
}

Received: 08.02.2019 / Accepted: 04.03.2019 / Revised: 30.04.2019 / Available online: 31.05.2019

DOI: 10.2478/jaes-2019-0007

KEY WORDS: Buildings and Related Industries, Energy Demand, Oil, Gas and Electricity, Modeling, LEAP.

\begin{abstract}
:
In this study, the demand of the Iran's energy carriers is analyzed and modeled for the country's largest consumer, buildings and related industries, in the status quo and future perspective. To this objective, the building sector is divided into two sections: household section (residential buildings) and services (business-office and service buildings) according to the ISIC classification that each of these sections is divided into sub-sections. In addition, building-related industries include some non-metallic minerals and basic metals industries. Regarding to scenario-based energy planning helps to increase the understanding of different probabilities in the future. The future outlook for the system is modeled with the horizon of 2035 with the LEAP modeling tool in the "reference" scenario, indicating the sustainability of the existing energy system in the future. The results of modeling indicate an increasing demand for energy as expected that energy demand carriers in buildings and related industries from 559.8 million barrels in 2014 reach up to 1040.6 million barrels of crude oil equivalents in 2035. Therefore, in order to reduce energy consumption, solutions are modeled and analyzed according to the scenarios for "Improvement of energy consumption in buildings and related industries", then the greenhouse gas emissions and their environmental effects are investigated.
\end{abstract}

\section{INTRODUCTION}

In recent decades, energy has played an important role in the countries' economic and political conditions. According to experts in the field may be the only way to save the world from the international economic crisis looked right into the energy issue (Pérez-Lombard, Ortiz et al. 2008, De Graaff 2012). In Iran, the boom or recession of economic and social activities has largely been influenced by the increase or decrease of oil production and income, although this income dependency has a great effect on the economy of our country. Although oil and gas resources are rich in our country, and our country is one of the first countries in terms of energy resources, but these reserves are endless (Hessari 2005, Brumberg and Ahram 2007). On the other hand, considering the investment opportunities of the oil sector and the constraints on harvesting wells, this process is more costly than the past, and this will challenge for the future of crude oil exports (Bakhoda, Almassi et al. 2012).
Based on Energy Balance Sheet 2014 (the last published Energy Balance Sheet), the comparison of Iran's energy status in 2014 with similar figures in 2006 shows that the total primary energy supply with annual growth of 3.8 percent from 1331.0 million barrels of crude oil equivalent in 2006 reached to 1799.4 million barrels of crude oil and total final consumption of energy with an annual growth of $3.1 \%$ from 709.4 increased to 1160.6 million barrels of crude oil (Energy 2014). During the survey period, the country's average annual energy exports has declined by 6.4 percent (Barteková and Kemp 2016). At present, the construction sector is the country's largest energy consumer, with a final consumption of $33.6 \%$ in 2014; however, with the completion of the country's energy supply, this is expected to decline in the future (Iran 2017). The final consumption trend of the building sector and its share in the total demand is presented in Table 1 and Figure 1. The growth in demand in the construction sector has been around 8 percent over the past eight years (The annual average during this period is $1 \%$ ).

\footnotetext{
* Corresponding author: Mehdi Ravanshadnia, e-mail: ravanshadnia@gmail.com
} 
Table 1. Demand trend and share of the building sector in the total final demand (energy and non-energy) (Iran 2017)

\begin{tabular}{|l|c|c|c|c|c|c|c|c|c|}
\hline Year & 2006 & 2007 & 2008 & 2009 & 2010 & 2011 & 2012 & 2013 & 2014 \\
\hline $\begin{array}{l}\text { Energy } \\
\text { consumption } \\
\text { (Million } \\
\text { barrels of oil } \\
\text { equivalents) }\end{array}$ & 410.47 & 433.97 & 414.97 & 429.77 & 421.97 & 429.97 & 405.34 & 438.48 & 443.79 \\
\hline $\begin{array}{l}\text { Share in total } \\
\text { final energy } \\
\text { demand(\%) }\end{array}$ & 41.46 & 40.14 & 37.51 & 37.10 & 37.18 & 36.30 & 34.29 & 35.69 & 33.60 \\
\hline
\end{tabular}

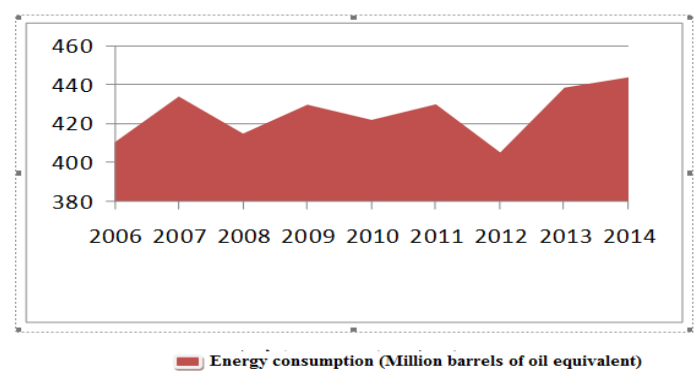

Figure 1. The demand for energy carriers in the Iranian building sector (studies 2011)

The model of the country's energy demand or supply system in various socio-economic sectors has been studied by many researchers. Studies have focused on a certain area and attempted to solve specific problems; they haven't intended to provide a comprehensive energy supply and a demand system for the relevant sector. Razini (2017) in a research entitled "Sustainable electrical energy development based on a multifactor model with a combination of policy-making and technical approach" has introduced a new strategy to model energy systems for a long-term developmental plan of electricity generation capacity using LEAP model (Razini 2017).

Also, Tafreshi (2010) studied the effects of energy policies of Iran in the field of power generation and the contribution of various types of power plants in the future (Tafreshi 2010). Using the LEAP model, the current state of electrical energy supply and demand has been investigated in Iran and provided possible answers to the question "When and what plants and capacities should be built in order to supply electricity properly?

Some other internal studies conducted by LEAP included of the estimation of the final energy demand until 2041 (Studies 2011), oil production and consumption planning (CBI 2006), and determination of the fuel basket in the transportation sector (Moshiri, Atabi et al. 2012). Among other studies, the energy system model proposed in Japan, with an emphasis on nuclear power and reducing greenhouse gases (Sovacool 2008) and the strategic planning model for China's energy production and consumption until 2030 (Wang, Gu et al. 2011).

Energy planning and management and also using energy and environmental policy design tools is one of the critical strategic issues that needs to be addressed in order to meet energy demand. Scenario-based modelling in the energy field is being considered around the world. In California, four scenarios have been introduced and analysed for energy planning until 2035 (Hoff 2011). This approach has also been used in China to better understand the possible paths for energy development in terms of fuel resources and degree of greenhouse gas emissions (Shan, Xu et al. 2012).

The results of the reference scenario indicate that demand growth of energy carriers is increasing in buildings and related industries. Meanwhile, high energy demand has swallowed a large part of oil and gas production and due to the fact that the bulk of the building is not productive, it will reduce the country's oil exports and reduce the country's power in organizations such as OPEC and GECF. On the other hand, the reduction of exports means the loss of country currency revenues and most importantly, the high energy consumption in building sector leads to a loss of national resources at the national level and the emission of environmental pollutants and greenhouse gases at the global level. Therefore, it is necessary to model scenarios based on energy consumption reduction strategies to deal with the damage resultant from high energy consumption in buildings and related industries.

In this regard, in this study, models are designed and analysed using Long Range Energy Alternative Planning (LEAP) software. LEAP is a tool to develop a model on both sides of supply and demand, in which highly complex data structures can be simulated and modelling, can be launched from zero point to cover all the specifications of the energy system. Hence, LEAP is not a model in itself, but rather it is a tool for extensive and comprehensive modelling.

\section{MATERIAL AND METHODS}

To implement the project, the LEAP energy and environmental modelling software was used. This software has the ability to cover the dimensions and dynamics of the energy system. In order to carry out more precise research, it is necessary to specify the framework of the project implementation and its stages. To do this, the below steps should be followed:

1) Identify the energy system, definition its boundaries and components.

2) Collecting data and information for modelling and analysing the energy system.

3) Drawing tree chart for the energy demand of the building sector and related industries in the LEAP environment. 
4) Processing and storing the data and preparing for entering in the model.

5) Designing the reference scenario, modelling and providing the required data in the model.

6) Running the model, correcting errors and confirming the results.

7) The analysis of the results in the reference scenario includes a study of the demand process of energy carriers in the construction and related industries.

8) Proposed possible scenarios for improving energy efficiency.

9) Implementing the model using different scenarios and analysing its results. Implement the model under scenarios and analyse the results.

The details are shown in Figure 2, which presents the algorithm and the process of calculations. The framework for implementing is based on this diagram.

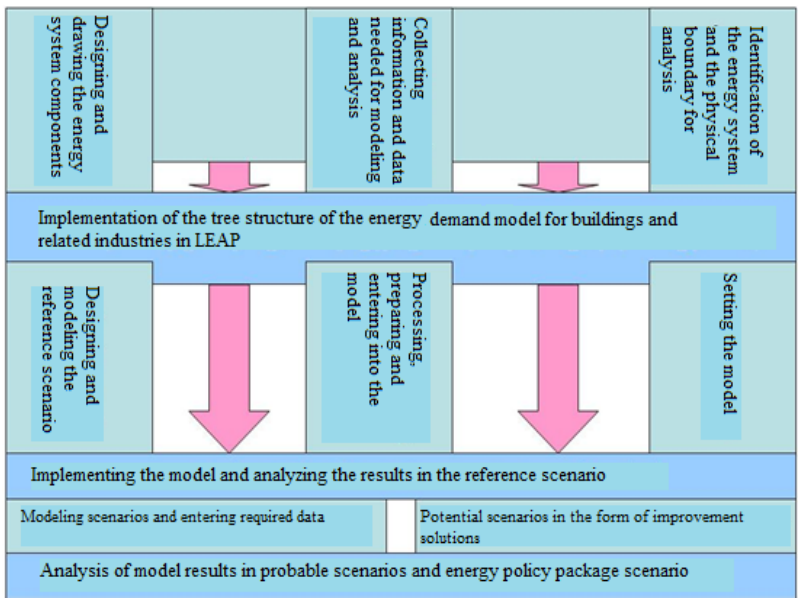

Figure 2. Methodology of research implementation

\subsection{LEAP modelling}

The LEAP Modelling is one of the simulation model of the energy system which given its capabilities and flexibility, allows for the simulation of the entire supply and demand system of energy. The LEAP modelling has the following main components that allow you to implement any particular idea in relation to the energy system in each component.

- Demand: There are many facilities for estimating the demand for energy carriers, including the annual demand for final energy, useful energy, and peak demand modelling, and so on.

- Transformation: Possibility of complete assembly of the components of the model supply. There is also the ability to compute the optimal combination of technology in the supply subsystems.

- Key Assumptions: providing the ability to enter data, parameters, and models directly and / or recall from other models and software.

- Resources: providing modelling fossil, renewable and non-commercial energy resources.
- Indicators: providing the ability to extract a variety of indicators and outputs with desired formulation. For example, since it is not possible to extract the intensity of energy consumption throughout the country, indicators allow obtaining the consumption intensity through dividing the total final energy consumption to the total value added.

In this study, the demand side includes buildings (household, services) and related industries.

\subsection{Demand side}

\subsubsection{Building sector}

The building sector consists of household and services sections. The residential section includes residential buildings that are responsible for living place and welfare of households. Unlike the household sector, the service sector is a productive one and alone provides about 60 percent of the country's value added. This part embraces activities requiring less-energy with a variety of educational, health, financial, insurance, public, government and military buildings, stores and shops, and so on. The difference between households and services in energy consumption can be summarized in Figure 3. Energy consumption in the household section is generally continuous in time, but energy consumption in the service section is discontinues in time.

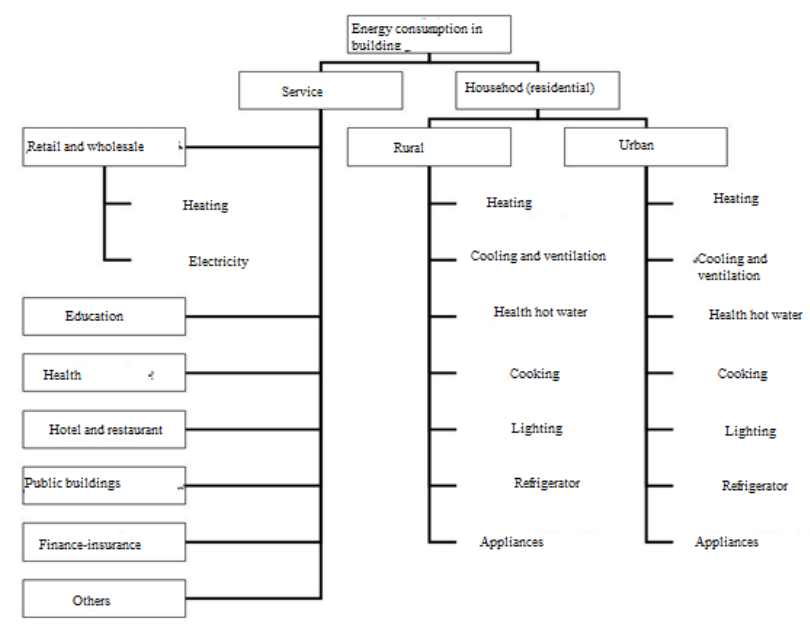

Figure 3. The structure of the building sector division for modelling

According to the Figure 3, the building sector is divided into two sections: household (residential buildings) and services (commercial, office and service buildings), each of which is classified into other subdivisions. Household buildings are divided into urban and rural constructions with different forms of energy consumers including indoor heating, cooling and ventilation, cooking, lighting, refrigerator and other uses. Commercial buildings are classified according to the statistical center of Iran to various subdivisions that each of these sub-sections is a consumer of a kind of energy carriers. The household represents the volume of activity of the household sector and also, according to the economic statistical center of Iran and the lack of information and 
infrastructure data, the value added index is also representative of the commercial sector. The data needed for the model are compiled from the three main sources of energy balance sheet published by Ministry of Power (2014), hydrocarbon energy balance sheet published by Ministry of Oil (2014) and energy balance sheet published by Statistics Center of Iran, which will be investigated in the following sections (Iran 2017).

\subsubsection{Building-related industry sector}

Major building-related industries are associated with non-metallic mineral industries and metal industries; their division is shown in Figure 4. Units such as tones and square meters were used for modeling energy consumption of industries.

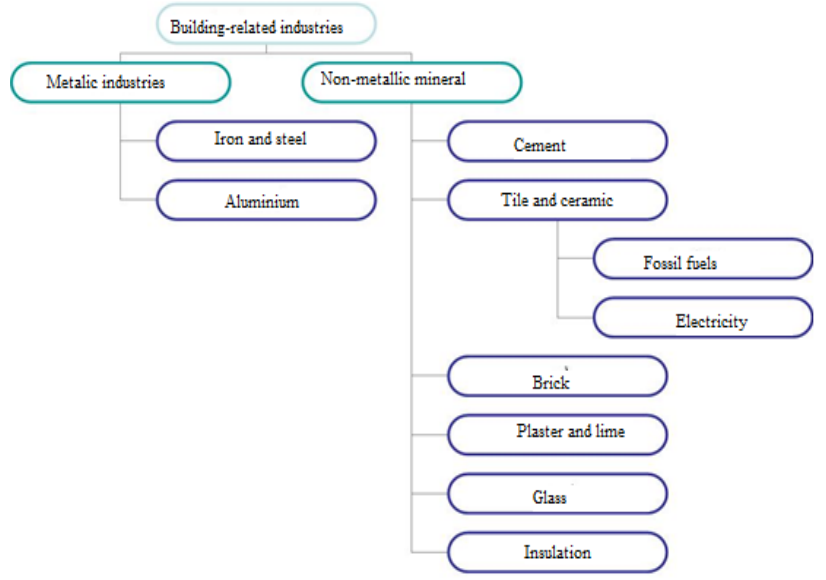

Figure 4. Industry division for LEAP modelling

\subsection{Energy modelling in LEAP}

Modelling energy in the LEAP modeller is an activity-level analysis method. In this method, energy demand is obtained from multiplying the activity volume (e.g. the number of households) by energy use intensity (e.g. per capita consumption of household gas for cooking). However, when the number of divisions grows, LEAP utilizes the following relations to calculate energy demand values.

$$
E_{i, j, t}=\sum_{k=1}^{K} \sum_{m=1}^{M} A_{i, j, k, m, t} \times E I_{i, j . k, m, t}
$$

Where: Ei,j.t represent the demand for energy carrier $\mathrm{j}$ in section $\mathrm{i}$, by GJ, kWh, or barrels of oil equivalent.

A: represents the activity level, which is calculated based on the activity level unit.

i: represents a sector that includes buildings and industry.

$\mathrm{j}$ : represents the type of energy carrier (e.g. natural gas and electricity, etc.)

$\mathrm{k}$ : refers to the underlying section (e.g. urban-rural section or nonmetallic minerals and metal industries).

$\mathrm{m}$ : represents the final consumption of energy such as for heating, lighting, hot water and so on.

$\mathrm{t}$ : refers to the year.

EIi, j, k, m, t: represents the intensity of energy use by the cubic meter per household, GJ per ton or J per real value added.

Emissions of pollutants are also obtained from the following equation:

$$
P_{p, j, t}=E_{j, t} \times E F_{j, t}
$$

Where: P p.j.t: indicates the amount of environmental emissions $p$ generated by the energy carrier $\mathrm{j}$ (e.g. natural gas) in year $\mathrm{t}$. Ejt: represents the amount of energy used by the energy carrier $\mathrm{j}$ in year $\mathrm{t}$.

$\mathrm{EFj}, \mathrm{t}$ : indicates the emission factor of the pollutants from fuel combustion $\mathrm{j}$ in year $\mathrm{t}$.

\subsection{Reference scenario by 2035}

The reference scenario reflects the continued existence status of the energy system in the future. The main point in the reference scenario is to determining the horizons of energy system modeling and providing the data needed for the main drivers of the energy system, including population growth and GDP, which is followed by all other sectors. In addition, two other parameters, household size and per capita income, will determine energy demand in the building sector. It is natural that the growth of the value added of the service sector is proportional to the growth of gross domestic product. Table 2 shows some of the data needed for the reference scenario.

\begin{tabular}{|c|c|c|c|c|}
\hline $\mathrm{NO}$ & Driver & Unit & $\begin{array}{l}\text { Index } \\
\text { value }\end{array}$ & Description \\
\hline 1 & $\begin{array}{l}\text { Average annual } \\
\text { population } \\
\text { growth of the } \\
\text { country }\end{array}$ & )$\%($ & 1.00 & $\begin{array}{c}\text { Statistical } \\
\text { Center of Iran }\end{array}$ \\
\hline 2 & $\begin{array}{l}\text { Average expected } \\
\text { economic growth } \\
\text { of the country in } \\
\text { the future }\end{array}$ & )$\%($ & 0.5 & $\begin{array}{c}\text { Scheduled } \\
\text { scenarios of } \\
\text { Schedule } \\
\text { Organization }\end{array}$ \\
\hline 3 & $\begin{array}{l}\text { Household size in } \\
2035\end{array}$ & $\begin{array}{l}\text { Person per } \\
\text { household }\end{array}$ & 30.2 & Estimated \\
\hline 4 & $\begin{array}{l}\text { Per capita income } \\
\text { of the country in } \\
2035\end{array}$ & $\begin{array}{c}1000 \text { Rials at } \\
\text { a fixed price } \\
\text { of } 1997\end{array}$ & 36.18 & Calculated \\
\hline
\end{tabular}

Table 2. Key data of the reference scenario

The beginning year for modelling was 2011, the simulated year was 2014, and the modelling planned horizon year was assumed to be 2035. The reference scenario was the basis on evaluating energy recovery solutions. In this section, the reference scenario data was analysed. The results include energy demand in the building sector and related industries, demand for electricity, natural gas and petroleum products, emission of greenhouse gases and pollutants, and greenhouse gas emission costs.

\section{RESULTS}

\subsection{Reference scenario modelling results}

The main energy carriers on demand side include natural gas, electricity and petroleum products. The demand for energy carriers was over 559.8 million barrels of oil equivalents in the building sector and related industries in 2015 , which is expected to reach about 1040.6 million barrels until 2035. The average annual energy demand growth was about 2.99 percent per year compared to 2014 . The total energy demand process will be as in Table 3 . 
Table 3. Demand for energy carriers in buildings and related industries (million barrels of oil equivalent)

\begin{tabular}{|c|c|c|c|c|c|c|c|c|c|c|c|c|}
\hline Sections & 2011 & 2012 & 2013 & 2014 & 2015 & 2016 & 2017 & 2021 & 2026 & 2031 & 2035 & $\begin{array}{c}\text { Average } \\
\text { growth(\%) }\end{array}$ \\
\hline Building & 403.9 & 385.2 & 413.7 & 424.4 & 433.6 & 448.8 & 462.7 & 520.6 & 602.7 & 697.8 & 785.5 & 2.98 \\
\hline Building-related industries & 122.7 & 128.6 & 131.8 & 135.5 & 136.5 & 143.4 & 148.5 & 168.3 & 195.4 & 226.6 & 255.1 & 3.06 \\
\hline Total & 526.6 & 513.8 & 545.6 & 559.8 & 570.1 & 592.2 & 611.2 & 688.9 & 798.1 & 924.4 & $1,040.6$ & 3.00 \\
\hline
\end{tabular}

The total natural gas demand for building and its related industries was over 1961.6 million GJ (52072.9 million cubic meters) in 2011, which with a relative growth, it increased to 2281.1 million GJ (60555 million cubic meters) in 2016. It is expected to reach about 4297.6 million GJ annually (114086.5 million cubic meters) by the planned horizon year (2035).

Electricity was also the second largest energy consuming carrier in buildings and the related industries, with consumption rate of about $109.15 \mathrm{GWh}$ per annum in 2011 and reached 141.0 GWh in 2016, and electricity demand is expected to grow fast in the reference scenario and increase approximately to $281.8 \mathrm{GWh}$ in 2035. The rapid increase in the number of residential units and the high share of the services sector in the country's gross domestic product is one of the main drivers of increasing demand for electricity. The average growth rate of electricity demand was about $3.79 \%$ in the building sector and $3.26 \%$ in the related industries sector in comparison with 2014. The use of major energy-producer oil products in buildings and related industries in 2011 was about 107.6 million barrels of oil equivalents, which was 94.47 million barrels in 2014 and 94.48 million barrels in 2016 that is expected to rise to a total of 95.9 million barrels of oil equivalents in 2035. Details of the process of demand for petroleum products in the building and related industries are shown in Table 4. As the documentation shows, it is expected that in the long run the average demand for petroleum products will remain constant, which is mainly due to the saturation of gas supply for urban and rural households.

Table 4. Average growth of demand for petroleum products in building and related industries until 2035 (Million barrels of oil equivalent)

\begin{tabular}{|c|c|c|c|c|c|c|c|c|c|c|c|c|c|}
\hline Total & 107.15 & 103.12 & 99.16 & 94.47 & 94.01 & 94.84 & 96.80 & 98.09 & 98.57 & 95.92 & 0.07 \\
\hline \multicolumn{10}{|c|}{ Share (\%) } \\
\hline Sectors & 2011 & 2012 & 2013 & 2014 & 2015 & 2016 & 2021 & 2026 & 2031 & 2035 & 77.63 \\
\hline Building & 84.33 & 83.92 & 84.03 & 84.20 & 84.80 & 84.45 & 83.41 & 82.46 & 80.26 & \\
\hline $\begin{array}{c}\text { Building- } \\
\text { related } \\
\text { industries }\end{array}$ & 15.67 & 16.08 & 15.97 & 15.80 & 15.20 & 15.55 & 16.59 & 17.54 & 19.74 & 22.37 & \\
\hline Total & 100 & 100 & 100 & 100 & 100 & 100 & 100 & 100 & 100 & 100 & \\
\hline
\end{tabular}

\subsection{Environmental emissions analysis}

The results of the model show that the total greenhouse gas emissions in this system in 2011 was about 281.6 million tons of carbon dioxide equivalents, which reached 299.9 million tons in 2014 and 306.9 million tons in 2016, and it is expected to rise by around 500.3 million tons in 2035 due to an average annual increase of $2.47 \%$. As seen in the table, despite that in most countries of the world greenhouse gas emissions are either stopped or relatively decreasing, greenhouse gas emissions are rising rapidly in Iran. The details of the greenhouse gas emission are shown in Table 5.

Table 5. The trend of greenhouse gas emissions in buildings and related industries in the reference scenario (million tons of carbon dioxide equivalent)

\begin{tabular}{|c|c|c|c|c|c|c|c|c|c|c|c|}
\hline Sectors & 2011 & 2012 & 2013 & 2014 & 2015 & 2016 & 2021 & 2026 & 2031 & $\begin{array}{c}2035 \\
\text { Average } \\
(\%)\end{array}$ \\
\hline Building & 137.2 & 131.7 & 139.1 & 139.8 & 142.4 & 146.3 & 164.6 & 184.8 & 207.1 & 226.6 & 2.32 \\
\hline $\begin{array}{c}\text { Building-related } \\
\text { industries }\end{array}$ & 144.4 & 151.9 & 153.9 & 160.0 & 153.4 & 160.6 & 193.3 & 213.6 & 241.3 & 273.7 & 2.59 \\
\hline Total & 281.6 & 283.6 & 293.0 & 299.9 & 295.8 & 306.9 & 358.0 & 398.5 & 448.4 & 500.3 & 2.47 \\
\hline
\end{tabular}




\subsection{Energy efficiency improvement scenarios}

The implementation of the 19th National Building Regulations, which addresses energy saving in buildings, is the first way to reduce energy consumption. Improved energy consumption, in particular thermal energy, by improving the form of climatebuilding architecture, improving insulation shells, designing optimal installations, and replacing fluorescent lamps and filament lamps with LED lamps and CFLs and with the implementation of energy efficiency standards for appliances and equipment can reduce the amount mentioned in the scenario analysis. In accordance with section 19 of National Building Regulations, the most important measures for this solution are the following:

- Energy saving by modifying construction plans.

- Improving the physical properties of the materials and thermal insulation systems used in the outer shell of the building.
- Optimal design of cooling, heating and ventilation and hot water systems.

- Providing optimal lighting for buildings.

Another proposed solution to reduce energy consumption is the development of new technologies, such as combined heat and power generation technology. CHP systems are a multipurpose technology that capable to supply electricity, heat, cooling (through absorption chillers) and dehydration. Also, they are capable to providing space heating and cooling along with hot water in building. The use of small ceiling wind turbines in residential buildings to reduce building power consumption, solar energy technology such as solar water heaters, solar absorption chillers, and ceiling solar cells for supplying buildings electricity are other ways that have been investigated (Table 6).

Table 6. Summary of strategies for reducing energy use and renewables development in buildings and related industries

\begin{tabular}{|c|c|c|}
\hline NO & $\begin{array}{c}\text { Solution, plan } \\
\text { and strategy }\end{array}$ & Description as scenario \\
\hline 1 & $\begin{array}{l}\text { Improving } \\
\text { energy use } \\
\text { efficiency in } \\
\text { buildings }\end{array}$ & $\begin{array}{l}\text { According to the Law on Energy Consumption Pattern Reform, relevant organizations such as Fuel } \\
\text { Conservation Optimization Company, SABTA and other organizations are responsible for implementing } \\
\text { energy efficiency measures in the building sector, which includes intelligentization of } 600,000 \text { building } \\
\text { powerhouses, the implementation of the } 19 \text { th National Building Regulations to improve the architectural- } \\
\text { climatic conditions of the building and to improve the shell by insulating and designing optimized energy } \\
\text { consumption facilities and replace fluorescent lamps and incandescent light bulbs with LED and CFLs } \\
\text { lamps. In this research, it is assumed that the set of these solutions will reduce energy consumption in the } \\
\text { urban sector at an average annual rate of } 2.1 \% \text {, and in the rural sector, it can reduce the annual energy use } \\
\text { until } 1.8 \% \text {.It also reduces thermal energy consumption by } 1.5 \% \text { annully in commercial buildings. It is } \\
\text { worth noting that due to various reasons, such as the development of new technologies, over time, the } \\
\text { development of ventilation systems does not only show a decrease in the intensity of electricity use in } \\
\text { commercial buildings, but it increases up to } 1 \% \text { or more annually. In this research, the average annual } \\
\text { growth of } 1 \% \text { was observed in commercial buildings consumption. }\end{array}$ \\
\hline 2 & $\begin{array}{l}\text { Improving } \\
\text { energy use } \\
\text { efficiency in } \\
\text { building-related } \\
\text { industries }\end{array}$ & $\begin{array}{l}\text { Building-related industries mainly constitute non-metallic minerals and basic metals industries, which } \\
\text { alone account for more than } 40 \% \text { of the total energy consumption of the country in the industry sector. } \\
\text { Short, medium and long-term solutions have been found to reduce energy consumption in these industries, } \\
\text { mainly focusing on cement, ceramic-tile, glass, steel producing and steel and aluminum products. } \\
\text { Improvement of processes, intelligentization of energy flow, increased controllability of existing systems, } \\
\text { compilation and enforcement of fuel consumption standards are among these solutions. The set of } \\
\text { solutions is expected to reduce power consumption by } 20 \% \text { and thermal energy use by at least by } 25 \% \\
\text { until the end of modeling. }\end{array}$ \\
\hline 3 & $\begin{array}{l}\text { Development of } \\
\text { synchronous } \\
\text { electricity and } \\
\text { heat production } \\
\text { technology }\end{array}$ & $\begin{array}{l}\text { The studies show that due to the need for high process temperatures, none of the building-related } \\
\text { industries, such as cement, glass, and steel, are able to use the technologies of simultaneous production of } \\
\text { electricity and heat. Therefore, this technology will only be used in buildings. According to the targeting } \\
\text { in the model, it is expected that with the continuation of the current incentives, the share of CHP } \\
\text { technologies in residential buildings will reach about } 5 \% \text { at the end of modeling and the share of rural } \\
\text { residential buildings will reach } 2 \% \text {. It's worth noting that in the model provided, all these default digits } \\
\text { can be changed .It is also expected that the share of CHP buildings will reach } 6 \% \text { at the end of modeling } \\
\text { in major commercial subdivisions such as educational, health and other buildings .Further details will be } \\
\text { provided on technologies for simultaneous production of electricity and heat. }\end{array}$ \\
\hline 4 & $\begin{array}{l}\text { Wind energy } \\
\text { development on } \\
\text { demand }\end{array}$ & $\begin{array}{l}\text { Using small ceiling turbines of } 300 \mathrm{~W} \text { to } 1 \mathrm{~kW} \text { can be a good option for using wind energy in residential } \\
\text { buildings. These wind turbines have a control package and can generally reduce the power consumption } \\
\text { of the building. The goal of this study is to provide a share of } 3 \% \text { for these turbines in residential buildings } \\
\text { and of } 5 \% \text { for commercial buildings at the end of modeling. Small turbines are mainly in } 300,400,500 \text {, } \\
600,800 \text { and } 1000 \mathrm{~W} \text { and are now available in the country. }\end{array}$ \\
\hline
\end{tabular}




\begin{tabular}{|c|c|l|}
\hline \multirow{5}{*}{5} & $\begin{array}{l}\text { The solar energy technology mostly includes solar water heaters, absorption chillers and ceiling solar } \\
\text { cells. All of these technologies have been commercialized and, of course, the cost of investing to exploit } \\
\text { them is still remarkable .In this research, it has been assumed that the development of solar water heater } \\
\text { will reach about 5\%, 7\% and 5\% for urban, rural and commercial buildings hot water supply at the end of } \\
\text { modeling (2035). This, although, is a conservative assumption, the history of the development of } \\
\text { renewable energies in Iran shows that this assumption is not far from reality. Ceiling photovoltaic cells in } \\
\text { most countries of the world are used to generate electricity for buildings that in the case of combination } \\
\text { with grids electricity and small wind turbines can reduce the amount of electricity purchased from the grid } \\
\text { and its cost. The technology's development limit of supplying electricity is assumed to increase up to 10\% } \\
\text { for residential buildings and up to 5\% for commercial buildings at the end of modeling. Solar absorption } \\
\text { chiller utilizes the solar thermal process and uses it in the absorption process for cooling. At the present } \\
\text { time, the commercial models of this technology are also available in Iran from the Hitachi and Ebara } \\
\text { demand } \\
\text { companies. It is assumed that the promotion of this technology in Iranian buildings will reach 3\% at the } \\
\text { end of modeling. }\end{array}$ \\
\hline
\end{tabular}

\subsection{Evaluation of the results of model implementation in different scenarios}

By extracting the results of the model resulting from the assessment of the five detailed scenarios, it shows that the demand for energy carriers in the construction sector and related industries will take various paths.
So that the energy demand ceiling of 1156.8 million barrels of crude oil equivalent in the reference scenario would be 961.7 million barrels of crude oil equivalent in the scenario "Improving energy efficiency in residential buildings". More details about the forecast process and the average amount of energy demand growth for each of the scenarios are shown in Table 7 and Figure 5.

Table 7. Comparison between different scenarios for energy demand in buildings and the related industries (million barrels of oil equivalent)

\begin{tabular}{|l|c|c|c|c|c|c|c|c|c|c|c|}
\hline \multicolumn{1}{|c|}{ Scenarios } & 2011 & 2012 & 2013 & 2014 & 2015 & 2016 & 2017 & 2021 & 2026 & $\begin{array}{c}2031 \\
\text { growth }\end{array}$ \\
\hline $\begin{array}{l}\text { CHP Development in } \\
\text { Buildings }\end{array}$ & 575.4 & 565.2 & 600.4 & 616.5 & 628.7 & 654.2 & 763.1 & 884.6 & $1,025.4$ & $1,154.8$ & 2.94 \\
\hline $\begin{array}{l}\text { Commercial Energy } \\
\text { Improvement }\end{array}$ & 575.4 & 565.2 & 600.4 & 616.5 & 628.5 & 653.5 & 759.4 & 876.8 & $1,011.9$ & $1,135.6$ & 2.86 \\
\hline $\begin{array}{l}\text { Demand side Solar Energy } \\
\text { Development }\end{array}$ & 575.4 & 565.2 & 600.4 & 616.5 & 628.9 & 654.4 & 763.7 & 885.8 & $1,027.1$ & $1,156.9$ & 2.95 \\
\hline $\begin{array}{l}\text { Demand side Wind Energy } \\
\text { Development }\end{array}$ & 575.4 & 565.2 & 600.4 & 616.5 & 628.9 & 654.4 & 763.6 & 885.6 & $1,026.8$ & $1,156.8$ & 2.94 \\
\hline $\begin{array}{l}\text { Household Energy } \\
\text { Improvement }\end{array}$ & 575.4 & 565.2 & 600.4 & 616.5 & 622.1 & 640.8 & 712.1 & 789.6 & 879.3 & 961.7 & 2.10 \\
\hline $\begin{array}{l}\text { Industry Energy } \\
\text { Improvement }\end{array}$ & 575.4 & 565.2 & 600.4 & 616.5 & 627.6 & 651.6 & 752.1 & 862.8 & 989.6 & $1,105.3$ & 2.73 \\
\hline Reference & 575.4 & 565.2 & 600.4 & 616.5 & 628.9 & 654.4 & 763.6 & 885.5 & $1,026.8$ & $1,156.8$ & 2.94 \\
\hline
\end{tabular}

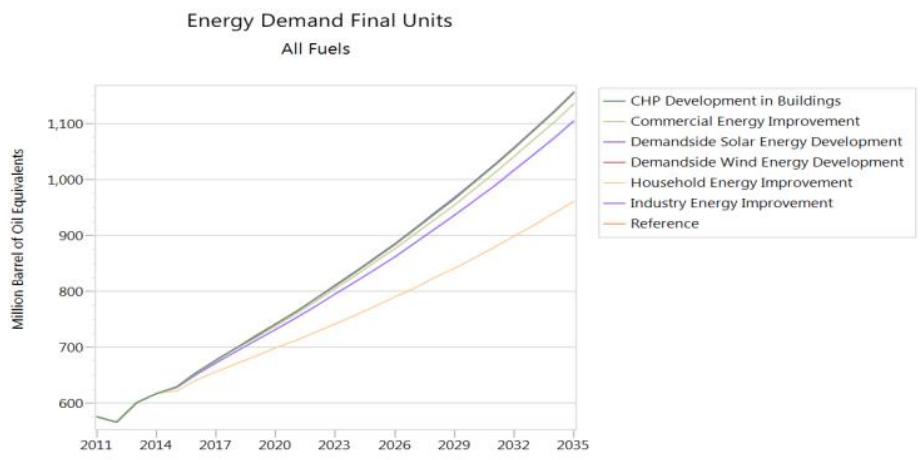

Figure 5. Comparison between different scenarios of energy demand in buildings and the related industries

The most important function of energy recovery and renewable energy development on demand side is proper use of energy as well as saving of consumption of fossil fuel carriers. Considering that the principle of saving is the key to managing the energy sector of the building and it can also result in macro-scale valuation and avoid waste of resources. Therefore, the exact expression of the amount of energy savings by implementing any solution can, in general, result in good savings in the building sector. As the results of the model show that the most energy saving is created in the energy efficiency improvement scenarios in the construction sector. For example, the 
scenario of improving energy efficiency (table 8, figure 6) in residential buildings was equivalent to 195 million barrels of crude oil and in commercial buildings it will be about 21.120 million barrels in 1414. Energy efficiency in construction sector with energy savings of 51.4 million barrels of crude oil was in the next rank.

Table 8. Estimation of energy saving in different scenarios in buildings and the related industries (million barrels of oil equivalent) Reference: Model Conclusions

\begin{tabular}{|r|c|c|c|c|c|c|}
\hline Scenarios & 2016 & 2017 & 2021 & 2026 & 2031 & 2035 \\
\hline CHP Development in Buildings & -2.714 & -3.387 & -6.552 & -11.783 & -18.836 & -26.270 \\
\hline Commercial Energy Improvement & -0.968 & -1.528 & -4.227 & -8.771 & -14.896 & -21.120 \\
\hline $\begin{array}{r}\text { Demand side Solar Energy } \\
\text { Development }\end{array}$ & -1.526 & -2.044 & -4.483 & -8.541 & -14.040 & -19.779 \\
\hline $\begin{array}{r}\text { Demand side Wind Energy } \\
\text { Development }\end{array}$ & -0.413 & -0.522 & -1.051 & -1.974 & -3.290 & -4.725 \\
\hline Household Energy Improvement & -13.531 & -20.573 & -51.214 & -95.429 & -146.820 & -194.332 \\
\hline Industry Energy Improvement & -2.818 & -4.361 & -11.467 & -22.745 & -37.141 & -51.404 \\
\hline Reference & - & - & - & - & - & - \\
\hline
\end{tabular}

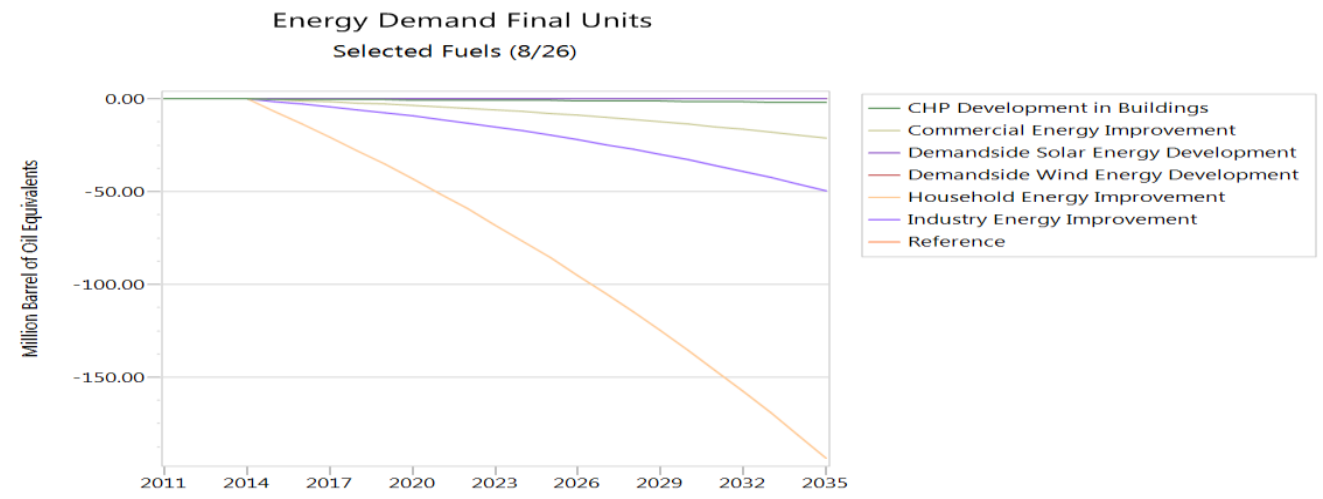

Figure 6. Estimation of energy savings in different scenarios in buildings and the related industries

Also, the study of the amount of environmental pollutants in different scenarios suggests that the total emissions of these gases in the scenario of improving energy efficiency in the building sector was about 214.3 million tons of carbon dioxide equivalent in 1414 which is the lowest among all scenarios.

In other scenarios, greenhouse gas emissions are equivalent range from 256.1 million tons of carbon dioxide to 270.3 million tons. Further details on the greenhouse gas emissions in various scenarios are presented in Figure 7 and Table 9.

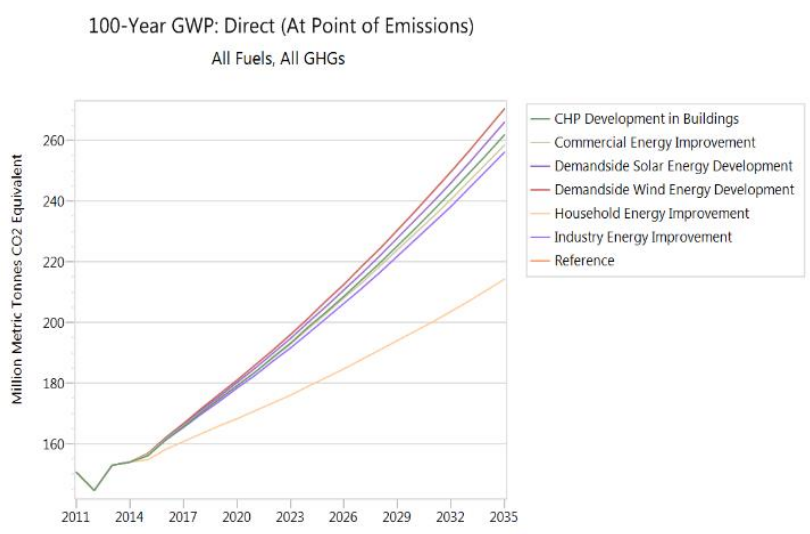

Figure 7. Emissions of environmental pollutants on demand side in different scenarios and their comparison with the reference scenario 
Table 9. Emissions of environmental pollutants on demand side in different scenarios and their comparison with the reference scenario (Million tons of carbon dioxide equivalent). Reference: Model Conclusions

\begin{tabular}{|l|c|c|c|c|c|c|c|c|c|c|}
\hline Scenarios & 2011 & 2012 & 2013 & 2014 & 2015 & 2016 & 2021 & 2026 & 2031 & 2035 \\
\hline CHP Development in Buildings & 150.8 & 144.7 & 153.2 & 154.2 & 156.2 & 161.3 & 183.7 & 208.7 & 236.8 & 261.8 \\
\hline Commercial Energy Improvement & 150.8 & 144.7 & 153.2 & 154.2 & 156.7 & 161.7 & 183.7 & 207.9 & 234.8 & 258.4 \\
\hline Demand side Solar Energy Development & 150.8 & 144.7 & 153.2 & 154.2 & 156.7 & 161.9 & 184.9 & 210.5 & 239.7 & 265.8 \\
\hline Demand side Wind Energy Development & 150.8 & 144.7 & 153.2 & 154.2 & 156.9 & 162.2 & 185.9 & 212.5 & 242.9 & 270.3 \\
\hline Household Energy Improvement & 150.8 & 144.7 & 153.2 & 154.2 & 154.9 & 158.2 & 170.9 & 184.7 & 200.4 & 214.3 \\
\hline Industry Energy Improvement & 150.8 & 144.7 & 153.2 & 154.2 & 156.5 & 161.4 & 182.7 & 206.2 & 232.6 & 256.1 \\
\hline Reference & 150.8 & 144.7 & 153.2 & 154.2 & 156.9 & 162.2 & 185.9 & 212.5 & 242.9 & 270.3 \\
\hline
\end{tabular}

Costs of environmental pollutants emissions vary according to the nature of different scenarios and in proportion to the emission of pollutants, from 2617.8 million $\$$ in the scenario of improving energy use efficiency in the building sector to the most value in the reference scenario. Environmental costs, although not yet considered in economic calculations of solutions and projects, are expected to play a key role in justifying industrial designs or implementing strategies in the future. The details of the costs of environmental pollutants emissions for buildings and related industries are shown in Figure 8 and Table 10.

Table10. Environmental costs on demand side in different scenarios and their comparison with the reference scenario (million dollars). Reference: Model Conclusions

\begin{tabular}{|c|c|c|c|c|c|c|c|c|c|c|}
\hline Scenarios & 2011 & 2012 & 2013 & 2014 & 2015 & 2016 & 2021 & 2026 & 2031 & 2035 \\
\hline $\begin{array}{l}\text { CHP Development in } \\
\text { Buildings }\end{array}$ & $1,868.6$ & $1,797.0$ & $1,884.0$ & $1,885.0$ & $1,902.3$ & $1,963.5$ & $2,227.3$ & $2,517.5$ & $2,854.8$ & $3,154.3$ \\
\hline $\begin{array}{l}\text { Commercial Energy } \\
\text { Improvement }\end{array}$ & $1,868.6$ & $1,797.0$ & $1,884.0$ & $1,885.0$ & $1,907.4$ & $1,968.1$ & $2,227.3$ & $2,509.0$ & $2,832.6$ & $3,116.7$ \\
\hline $\begin{array}{l}\text { Demand side Solar } \\
\text { Energy Development }\end{array}$ & $1,868.6$ & $1,797.0$ & $1,884.0$ & $1,885.0$ & $1,907.7$ & $1,969.9$ & $2,239.9$ & $2,509.0$ & $2,887.3$ & $3,199.4$ \\
\hline $\begin{array}{l}\text { Demand side Wind } \\
\text { Energy Development }\end{array}$ & $1,868.6$ & $1,797.0$ & $1,884.0$ & $1,885.0$ & $1,909.8$ & $1,973.4$ & $2,251.2$ & $2,560.4$ & $2,923.4$ & $3,249.9$ \\
\hline $\begin{array}{l}\text { Household Energy } \\
\text { Improvement }\end{array}$ & $1,868.6$ & $1,797.0$ & $1,884.0$ & $1,885.0$ & $1,930.4$ & $1,928.8$ & $2,082.0$ & $2,246.5$ & $2,443.1$ & $2,617.8$ \\
\hline $\begin{array}{l}\text { Industry Energy } \\
\text { Improvement }\end{array}$ & $1,868.6$ & $1,797.0$ & $1,884.0$ & $1,885.0$ & $1,870.4$ & $1,961.9$ & $2,204.7$ & $2,469.3$ & $2,775.3$ & $3,045.7$ \\
\hline Reference & $1,868.6$ & $1,797.0$ & $1,884.0$ & $1,885.0$ & $1,909.8$ & $1,973.4$ & $2,251.2$ & $2,560.4$ & $2,923.4$ & $3,249.9$ \\
\hline
\end{tabular}

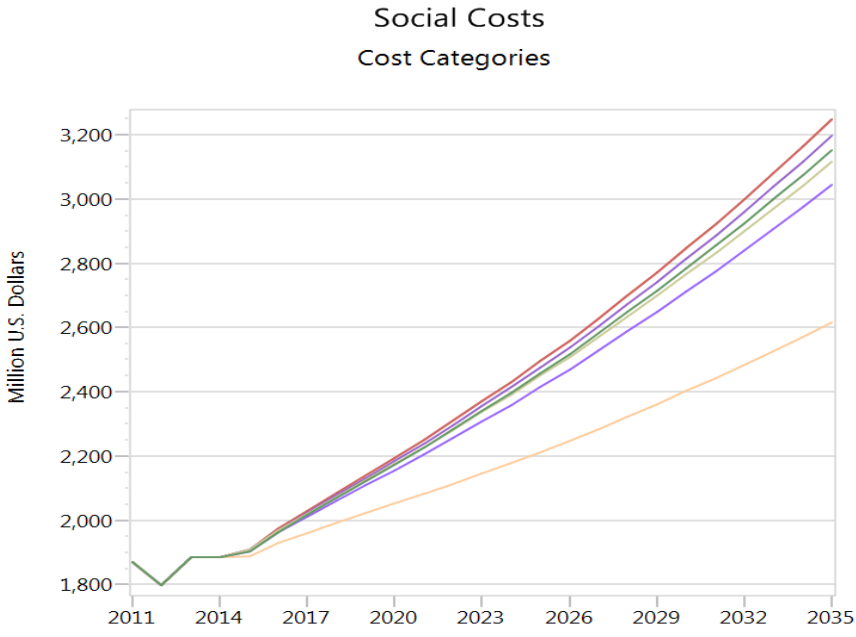

$$
\begin{aligned}
& \text { - CHP Development in Buildings } \\
& \text { _ Commercial Energy Improvement } \\
& \text { — Demandside Solar Energy Development } \\
& \text { — Demandside Wind Energy Development } \\
& \text { - Household Energy Improvement } \\
& \text { - Industry Energy Improvement } \\
& \text { Reference }
\end{aligned}
$$

Figure 8. Environmental costs on demand side in different scenarios and their comparison with the reference scenario 


\section{CONCLUSION}

In this paper, energy demand in Iran's buildings and the related industries was modelled using the LEAP modeller, and the energy demand perspective at the horizon 2035 was analysed by the emphasis on the continuation of previous policies under the reference scenario. The results of the detailed scenario analysis suggest that the demand for energy carriers in buildings and the related industries takes different paths so that the peak of energy demand will reach 1156.8 million barrels of oil equivalents and the least amount of it in the scenario "Improving energy use efficiency in residential buildings" will be 961.7 million barrels of oil equivalents. The most energy savings in energy use efficiency scenarios are achieved in the building sector. For example, the efficient energy use is equivalent to 195 million barrels of oil for residential buildings and 21.120 million barrels per annum for commercial buildings in 2035. Energy use efficiency in the building industry, with energy savings of 51.4 million barrels of oil equivalents, lies at the next level. Moreover, the evaluation of environmental pollutants emissions in different scenarios indicates that the total amount of emissions in the scenario of improving energy use efficiency will be about 214.3 million tons of carbon dioxide equivalents for the building sector in 2035, which is the least amount in all scenarios. In other scenarios, the amount of greenhouse gas emissions ranges from 256.1 to 270.3 million tons of carbon dioxide equivalent.

\section{References:}

Bakhoda, H., et al. (2012). "Energy production trend in Iran and its effect on sustainable development." Renewable Sustainable Energy Reviews 16(2): 1335-1339.

Barteková, E. and R. Kemp (2016). "National strategies for securing a stable supply of rare earths in different world regions." Resources Policy 49: 153-164.

Brumberg, D. and A. I. Ahram (2007). "The National Iranian oil company in Iranian politics." Japan Petroleum Energy Center the James 18: 121-132.

CBI (2006). "National Accounts Annual Reports: Economic Indicators. Central Bank of Iran: Quarterly Reports (Economic Indicators), Tehran.".

De Graaff, N. (2012). "Oil elite networks in a transforming global oil market." International Journal of Comparative Sociology 53(4): 275-297.

Energy, M. o. (2014). Ministry of Energy. Energy balance sheets. Hessari, F. (2005). "Sectoral energy consumption in Iran." Renewable Sustainable Energy Reviews 9(2): 203-214.

Hoff, H. (2011). "Understanding the nexus. Background paper for the Bonn 2011 Conference: The water, energy and food security nexus." Stockholm Environment Institute, Stockholm 20: 120129.
Iran, S. C. o. (2017). Report on the rate of economic growth of the country, Iran's Statistics Center, President Deputy Strategic Planning and Control.

Moshiri, S., et al. (2012). "Long run energy demand in Iran: a scenario analysis." International Journal of Energy Sector Management 6(1): 120-144.

Pérez-Lombard, L., et al. (2008). "A review on buildings energy consumption information." Energy buildings 40(3): 394-398.

Razini, S. (2017). "Sustainable Electrical Energy Development in Iran based on mulitafactor model." Energy 20: 148-156.

Shan, B.-g., et al. (2012). "China's energy demand scenario analysis in 2030." Energy Procedia 14: 1292-1298.

Sovacool, B. K. (2008). "Valuing the greenhouse gas emissions from nuclear power: A critical survey." Energy Policy 36(8): 2950-2963.

Studies, I. E. (2011). Oil and gas consumption in country. Institute for Energy Studies, Annual Report, Tehran.

studies, I. f. I. E. (2011). "Estimation of the Final Demand by the year 2014, Tehran."

Tafreshi, S. M. (2010). "Scenario planning for the Electricity Generation in Iran." Energy Policy 35: 2352-2359.

Wang, Y., et al. (2011). "Recent development of energy supply and demand in China, and energy sector prospects through 2030." Energy Policy 39(11): 6745-6759. 